\title{
Molecular phylogeny of the South American sheldgeese with implications for conservation of Falkland Islands (Malvinas) and continental populations of the Ruddy-headed Goose Chloephaga rubidiceps and Upland Goose C. picta
}

\author{
MARIANA BULGARELLA, CECILIA KOPUCHIAN, ADRIÁN S. DI GIACOMO, \\ RICARDO MATUS, OLIVIA BLANK, ROBERT E. WILSON \\ and KEVIN G. MCCRACKEN
}

\begin{abstract}
Summary
Sheldgeese of the genus Chloephaga are waterfowl (Anatidae) endemic to mainland South America and the Falkland Islands (Malvinas). Continental populations of three species C. picta, C. poliocephala, and C. rubidiceps breed in Patagonia and Tierra del Fuego and migrate northwards to winter in central Argentina and Chile. These continental populations have declined by $>50 \%$ in the past 30 years due to direct hunting to control crop damage and by the introduction of the grey fox Dusicyon griseus to their breeding grounds in Tierra del Fuego. The continental population of C. rubidiceps is critically endangered, estimated to be $<1$, ooo individuals. While no historic population size estimates exist for C. rubidiceps in its wintering grounds, the breeding population in Tierra del Fuego was estimated to number several thousand individuals in the 1950s. In contrast, the C. rubidiceps population in the Falkland Islands (Malvinas) is non-migratory and stable with $>42,000$ individuals, as is the Falkland Islands (Malvinas) population of C. picta leucoptera with $>138,000$ individuals. Here we use sequence data from the mitochondrial DNA control region to quantify genetic divergence between insular and continental populations of these two species of sheldgeese. Chloephaga rubidiceps and C. picta showed significant intraspecific differentiation of $1.0 \%$ and $0.6 \%$, respectively. In both cases, mainland and insular populations were reciprocally monophyletic and did not share mtDNA haplotypes. These results suggest that the insular and continental populations of C. rubidiceps and C. picta are genetically distinct and that female-mediated gene flow is restricted. We recommend a reevaluation of the threat category status of the continental C. rubidiceps population, under IUCN guidelines. It is necessary to implement urgent actions for the conservation of this critically endangered population.
\end{abstract}

\section{Resumen}

El género Chloephaga comprende aves acuáticas (Anatidae) endémicas del continente Sudamericano y las Islas Malvinas. Las poblaciones continentales de tres especies C. picta, C. poliocephala y C. rubidiceps reproducen en Patagonia y Tierra del Fuego y migran hacia el norte para invernar en Argentina y Chile central. Estas poblaciones continentales han declinado $>50 \%$ en los últimos 30 años debido a la caza directa para controlar el daño a las cosechas o por la introducción del zorro gris, Dusicyon griseus, en sus áreas de reproducción en Tierra del Fuego. La población continental de C. rubidiceps está en peligro crítico, se estima que quedan < 1000 individuos. Mientras no 
existen estimaciones históricas del tamaño poblacional para C. rubidiceps en sus áreas de invernada, se estimó que la población reproductiva en Tierra del Fuego consistía de varios miles de individuos en los años '50. En cambio, la población de C. rubidiceps de las Islas Malvinas es no migratoria y se considera estable con $>42000$ individuos, del mismo modo que la población de C. picta leucoptera de las Islas Malvinas con > 138000 individuos. Aquí usamos la información de secuencias de la región de control del ADN mitocondrial para cuantificar la divergencia genética de las poblaciones insulares y continentales de estas dos especies. Chloephaga rubidiceps y C. picta presentaron una diferenciación intraespecífica significativa del $1 \%$ y del o,6\%, respectivamente. En ambos casos, las poblaciones insulares y del continente fueron recíprocamente monofiléticas y no compartieron haplotipos. Estos resultados sugieren que las poblaciones insulares y continentales de C. rubidiceps y C. picta son genéticamente distintas y que el flujo génico mediado por las hembras está restricto. Se recomienda una reevaluación del status de la categoría de amenaza de la población continental de C. rubidiceps, bajo regulaciones de la IUCN. Es necesario implementar acciones urgentes de conservación de esta población en peligro crítico.

\section{Introduction}

Oceanic island ecosystems have been recognised as natural laboratories for studying evolution owing to their discrete geographical nature and diversity of species and habitats (Brown and Lomolino 2000, Lomolino 2000, Emerson 2002). Species richness within islands can be the result of a number of factors, including the diversification of a founding population into an array of species differentially adapted to diverse environmental niches, multiple successful colonisations of islands from neighbouring islands or continents, the diversification of a founding population by vicariance, and speciation through bottleneck and founder flush events (Templeton 1980, Carson and Templeton 1984, Clegg et al. 2002, Maley and Winker 2010). Phylogenetic data can shed light on the processes that have led to species diversity on islands and the understanding of their origins (Emerson 2002).

The Falkland Islands (Malvinas) are located at $52^{\circ} \mathrm{S}$ in the South Atlantic, approximately $450 \mathrm{~km}$ from Tierra del Fuego and $600 \mathrm{~km}$ east of mainland Argentina (Figure 1 ). They lie close to the edge of the Patagonian continental shelf, and are influenced by the Falkland Current that derives from the westward wind drift around the Southern Ocean (McDowall 2005). Geological evidence suggests that the Falkland Islands (Malvinas) were historically adjacent to south-eastern Africa and reached their present position and orientation by the late Mesozoic approximately 130 Mya (Storey et al. 1999, Trewin et al. 2002). There are strong similarities between the biota of the Falkland Islands (Malvinas) and southern South America, including numerous island endemic species or subspecies. The avifauna comprises c.36 land and freshwater species (Woods 1988, Strange 1992). There is only one recognised Falkland endemic bird species, the Falkland Steamer Duck Tachyeres brachypterus (Weller 1972). In several instances, the bird fauna is characterised by two or more species per genus, but in all cases the insular species of such genera are also present in Patagonia. It is believed that the Patagonian biota reached the Falkland Islands (Malvinas) either across a former land connection, in periods of lowered sea levels during Pleistocene glaciations, or across an ocean gap thorough dispersal from Patagonia (McDowall 2005).

The sheldgeese Neochen and Chloephaga comprise six species of waterfowl endemic to South America. With the exception of the Orinoco Goose Neochen jubata, they are distributed in the southern part of the continent along the Andes and Patagonia. Four of the five species also occur on the Falkland Islands (Malvinas) (Figure 1 ).

Neochen is monotypic, inhabiting rivers and wetlands in the tropical rainforests and savannas of northern South America (Johnsgard 1978). The Andean Goose Chloephaga melanoptera is resident to the Andes above 3,00o m elevation from Peru to the latitude of Mendoza in Argentina and Nuble in Chile; no subspecies are recognised (Johnsgard 1978). Breeding distribution of the Ashy-headed Goose Chloephaga poliocephala is strongly associated with the Nothofagus forest of Andean Patagonia from $37^{\circ} \mathrm{S}$ to Tierra del Fuego (Kear 2005). The species, with no recognised 


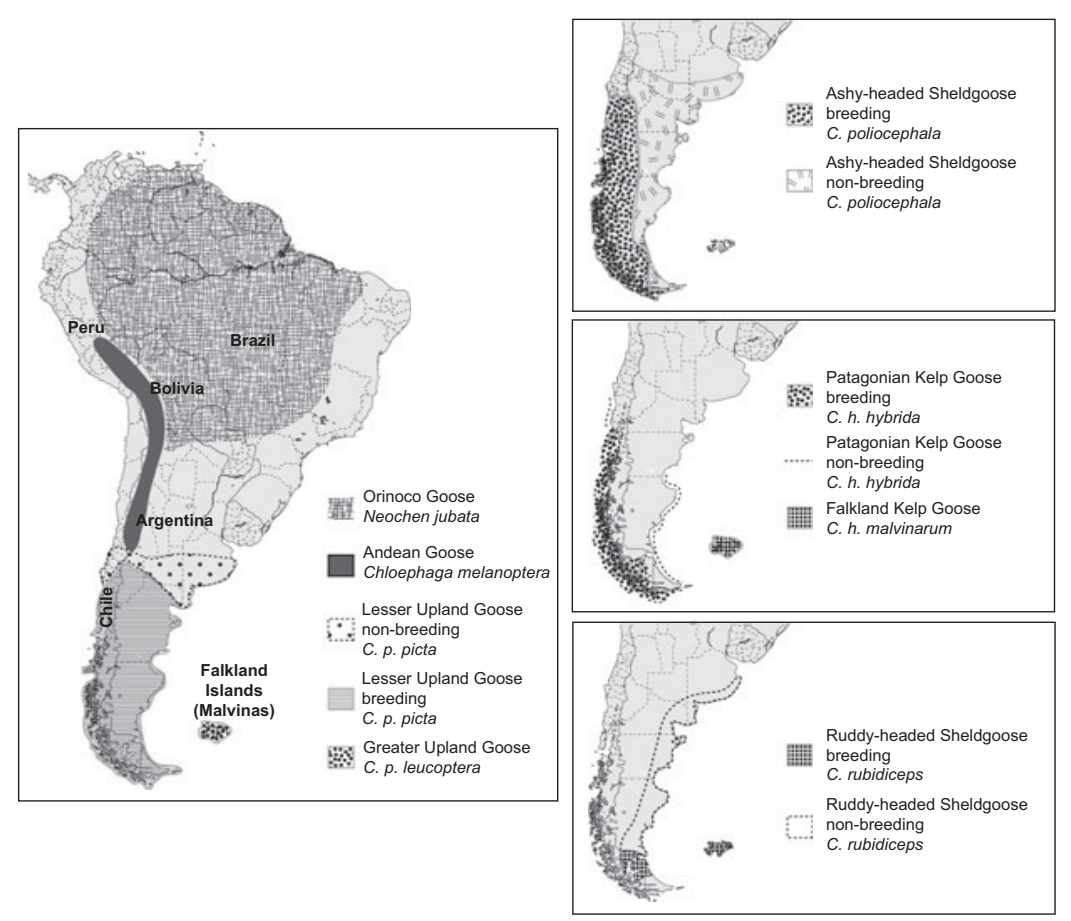

Figure 1. Breeding and non-breeding distribution of the Chloephaga and Neochen species described in this study. Redrawn from Johnsgard (1978) with updates from Kear (2005).

subspecies, is more common in Chile than anywhere else in its range and is rare in the Falkland Islands (Malvinas) (Johnsgard 1978). The Upland Goose Chloephaga picta has two recognised subspecies; C. p. picta inhabits the mainland, and C. p. leucoptera is a non-migratory resident of the Falkland Islands (Malvinas) (Johnsgard 1978, Carboneras 1992). The Kelp Goose Chloephaga hybrida also has a resident population in the Falkland Islands (Malvinas), C. h. malvinarum, and a partially migratory population, C. h. hybrida, on the coast of Patagonia in Chile and Argentina, including Tierra del Fuego (Carboneras 1992). Finally, the Ruddy-headed Goose Chloephaga rubidiceps also occurs in two distinct populations, a migratory population that breeds in Tierra del Fuego and nearby in mainland Chile and Argentina, and a non-migratory population in the Falkland Islands (Malvinas) (Carboneras 1992; Figure 1). No subspecies of C. rubidiceps are currently recognised.

Sheldgeese populations in the Falkland Islands (Malvinas) seem to be stable whereas continental populations have declined (Wetlands International 2006). In mainland southern South America, three of the species breed in southern Patagonia and Tierra del Fuego and migrate northwards during the winter to central Argentina and Chile: C. picta, C. poliocephala and C. rubidiceps. In Argentina, they were declared an agricultural pest in 1964 (Rumboll 1975), when population control programmes were implemented. Control methods included mass destruction of nests and eggs in the breeding grounds and uncontrolled hunting in the wintering grounds (Pergolani de Costa 1955, Blanco and de la Balze 2006). In 1947, 250,000 eggs were destroyed (Delacour 1954), and 150,000 eggs per year in the 1970s (Weller 1975) in Tierra del Fuego alone. These eradication techniques decreased the sheldgeese populations in Argentina, especially C. rubidiceps (Rumboll 1975). In northern Tierra del Fuego, Crawshay (1907) recorded sheldgeese as 'countless' during the breeding season, and C. rubidiceps as the most abundant species (Scott 1954). However, current population estimates of $C$. rubidiceps are $768-1,178$ individuals in the breeding grounds 
of Chile and Argentina (Madsen et al. 2003, Blanco and de la Balze 2006). Population declines > 50\% were also recorded in censuses of wintering areas in southern Buenos Aires province (Blanco et al. 2009). For the three species of sheldgeese wintering in Buenos Aires more than 35,000 individuals were counted in 1976, 16,547 in 1984, and 9,278-13,618 individuals during 2007-2009 (Petracci 2008, 2009, 2010), suggesting that sheldgeese have declined by approximately two-thirds.

Therefore, it is necessary to establish whether the continental populations of sheldgeese represent a significant unit for conservation, either evolutionarily or for management. Evolutionarily significant units (ESU) have been defined as reciprocally monophyletic for mitochondrial DNA (mtDNA) alleles and showing significant divergence of alleles at nuclear loci, whereas management unit (MUs) have been recognised as populations with significant divergence of allele frequencies at nuclear or mitochondrial loci, regardless of the phylogenetic distinctiveness of the alleles (Moritz 1994). The focus of the MU is on contemporary population structuring and short-term monitoring rather than historical factors. However, consensus about the applicability of the concepts of ESU and MU is lacking (Crandall et al. 2000, Green 2005). Fraser and Bernatchez (2001) proposed a unifying concept for defining conservation units, and suggested that the best available biological information be used when exercising such decisions on a case-by-case basis. Despite the controversy, we aimed at defining areas of importance for sheldgeese conservation.

Motivated by the critical decrease of continental populations of sheldgeese, and the taxonomic uncertainty of continental versus island populations, we used mtDNA to compare and quantify divergence between populations of two species of particular interest C. rubidiceps and C. p. pictal leucoptera inhabiting the Falkland Islands (Malvinas) and continental South America (southern Chile and Argentina). By incorporating multiple samples for each Chloephaga species and Neochen jubata, we also generated a phylogeny for all species of sheldgeese and provided a likely biogeographic scenario for the split of the insular and mainland sheldgeese populations.

\section{Methods}

\section{Sampling, PCR, and DNA sequencing}

We collected blood or tissue samples from all six species of sheldgeese, including three insular populations from the Falkland Islands (Malvinas). These included Neochen jubata $(n=1)$, C. melanoptera $(n=10)$ from Peru, Bolivia, and Argentina; C. poliocephala from Argentina $(n=4)$; C. rubidiceps from Chile $(n=9)$ and the Falkland Islands (Malvinas) $(n=6)$; C. p. picta from Argentina $(n=15)$ and C. p. leucoptera $(n=28)$ from the Falkland Islands (Malvinas), and C. hybrida malvinarum $(n=3)$ from the Falkland Islands (Malvinas) (Figure 1 ). Five representative dabbling ducks Anas crecca crecca, A. c. carolinensis, A. acuta, A. americana and A. clypeata were selected as outgroups. Anas dabbling ducks are appropriate outgroups as shown by varied datasets and analyses (Donne-Goussé et al. 2002, Gonzalez et al. 2009, Bulgarella et al. 2010).

DNA sequences were obtained using modified protocols for DNA extraction, PCR, and sequencing (McCracken and Sorenson 2005). We amplified and sequenced $636 \mathrm{bp}$ corresponding to the $5^{\prime}$-end of the mtDNA control region from each of the 81 sampled specimens. We initially used the overlapping primer pairs L78-H774 (Sorenson and Fleischer 1996, Sorenson et al. 1999), but after initial inspection of the sequences and preliminary data analyses, we determined that all DNA extracts obtained from blood yielded co-amplified or purely nuclear mtDNA (numts; e.g. Sorenson and Quinn 1998), putative copies of the mtDNA sequence (GenBank accession numbers KC109081-KC109104). We therefore redesigned a 5' forward primer Lio8-Chloephaga (CATATATTTATATGCCCCATACAATTTAGA) to selectively amplify the mtDNA sequences we obtained from muscle tissue extracts. This 30-bp primer is mostly identical to the mtDNA template at all sites but mismatches the nuclear sequence at the last position on the $3^{\prime}$-end (the nuclear copy possesses a $\mathrm{G}$ at the last site whereas the mtDNA possesses an A at this site). Additionally, Neochen and C. melanoptera each posses a deletion of the A nucleotide at position 24 (relative to the primer), but since we amplified these two species from muscle we were able to 
obtain clean mtDNA sequences using the $\mathrm{L} 78$ primer. The DNA extracted from blood samples from C. p. leucoptera inhabiting the Falkland Islands (Malvinas) were determined to have CG at the first and second position of the Lio8 primer, respectively, whereas the mtDNA template possessed CA in all six species. Thus, we were able to preferentially amplify and sequence the mtDNA copy, as well as the nuclear copy from blood samples using allele-specific priming (Bottema et al. 1993, Peters et al. 2005). Sequences from opposite strands were reconciled and verified for accuracy using Sequencher v.4.7 (Gene Codes, Ann Arbor, Michigan). Sequences and specimen voucher information, including geo-referenced localities, are archived in GenBank (accession numbers KC109005-KC109080, HMo63476-HMo63480).

\section{Phylogenetic analysis}

The control region sequences for Neochen and Chloephaga were aligned by eye. However, when we included the five Anas dabbling ducks species as outgroup taxa, the sequences varied in length due to insertions and deletions of nucleotides. We therefore aligned control region sequences for Chloephaga, Neochen, and Anas using the Geneious v.5.4 (Drummond et al. 2011) alignment algorithm with the default parameter settings.

We first constructed a simple UPGMA tree by using the HKY genetic distance method as implemented in Geneious v.5.4, with a resampling of 1 ,ooo bootstrap replicates. Secondly, we used AIC (Akaike 1973) as implemented in Modeltest 3.7 (Posada and Crandall 1998) to determine the model of sequence evolution that best fit the data. We then conducted a maximum likelihood analysis as implemented in the PhyML (Guindon and Gascuel 2003) plug-in for Geneious v5.4. Statistical support for clades was evaluated by 1,000 replicate nonparametric bootstrapping (Felsenstein 1985). Clade probabilities were obtained from the posterior distribution using MrBayes v.3.2.o (Ronquist and Huelsenbeck 2005). Bayesian analyses were replicated twice, each with four Markov chains of 2.5 million generations. Trees were sampled every 1,0oo generations, of which the first 0.5 million generations were discarded as burn-in.

Furthermore, to examine population differentiation of C. rubidiceps and C. p. picta/leucoptera between the Falkland Islands (Malvinas) and continental South America, we calculated $\Theta_{\mathrm{ST}}$ for each population of sheldgeese using the Tamura and Nei (1993) nucleotide substitution model in Arlequin v3.5 (Excoffier and Lischer 2010), with a significance level of 0.05. To determine the existence (or not) of shared haplotypes, we drew an allelic network calculated using the medianjoining algorithm in NETWORK V.4.I (Bandelt et al. 1999).

\section{Results}

\section{Numts sequencing}

Population-level samples of sheldgeese mitochondrial DNA have not been previously published, due in part to the fact that DNA extracts obtained from blood frequently yield co-amplified or purely nuclear mtDNA (numts) copies of the mtDNA sequence in these species. Figure $\mathrm{S}_{1}$ in the online supplementary material shows the most parsimonious tree constructed with sequences comprising a mix of putative numts (extracted from blood, shown in bold) and mtDNA copies. The numts were an average of $3.21 \%(2.68-5.52 \%)$ divergent from the nearest mtDNA copy.

\section{Phylogenetic analysis}

The UPGMA tree grouped C. melanoptera and N. jubata as sister taxa, and sister to all other Chloephaga species. Chloephaga rubidiceps from the Falkland Islands (Malvinas) formed a reciprocally monophyletic clade with $C$. rubidiceps from Chile, with an average uncorrected sequence divergence of $1.03 \%$ (0.94-1.26\%). Chloephaga rubidiceps was sister to C. poliocephala. This clade was in turn sister to C. hybrida plus C. picta (Figure 2). 


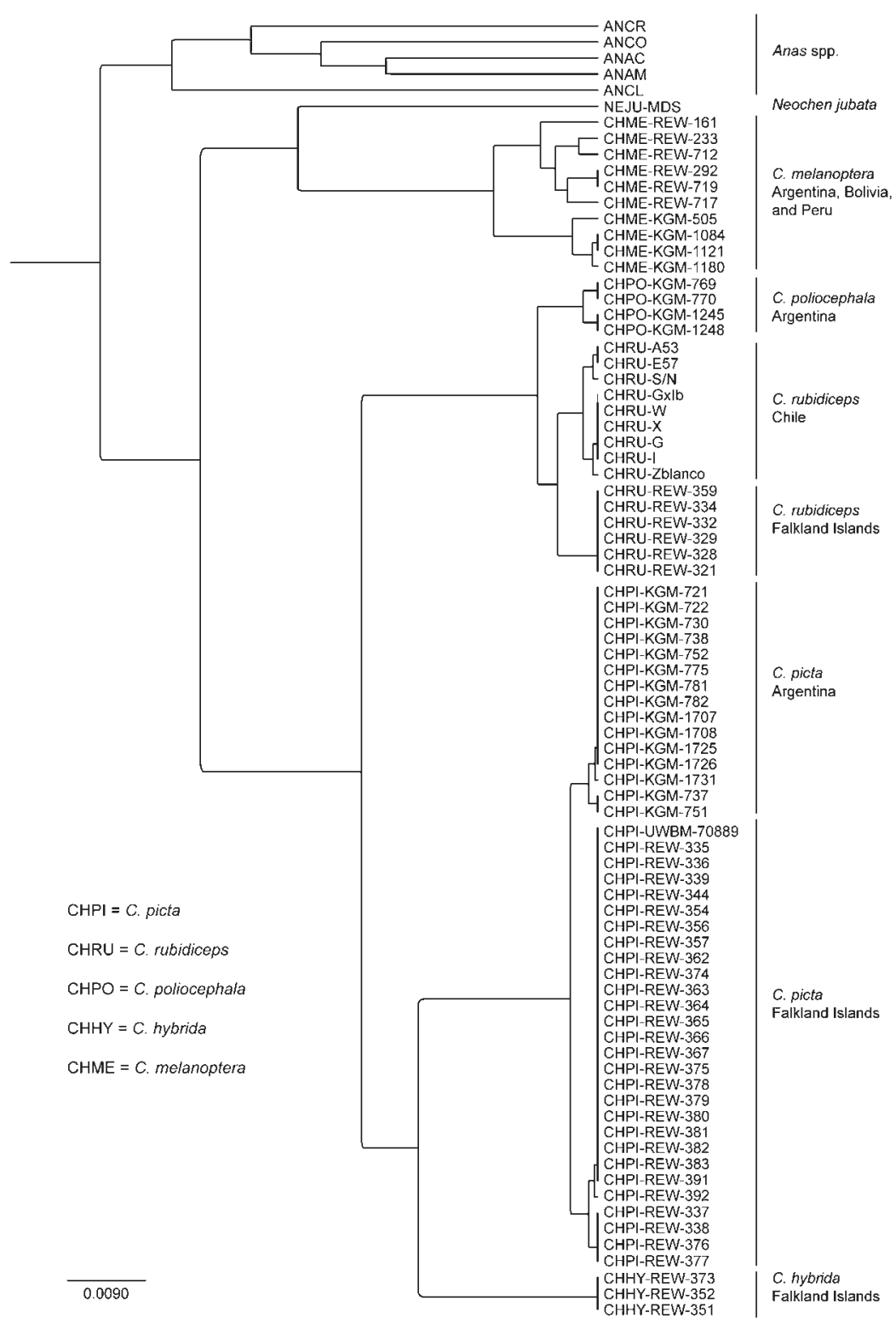

Figure 2. UPGMA tree showing the grouping of the Chloephaga genus and Neochen jubata. Five representative Anas spp. were selected as the outgroup.

No haplotypes were shared between C. rubidiceps populations from the Falkland Islands (Malvinas) and Chile or between C.p. picta from Argentina and C. p. leucoptera from the Falkland Islands (Malvinas) (Figure 3, Figure S2). Both clades of C. picta were reciprocally monophyletic with an uncorrected sequence divergence of $0.59 \%$ (0.31-0.79\%), defined by three transitions at positions 85, 109, and 317, respectively. Pairwise $\Theta_{\mathrm{ST}}$ for the two C. picta populations was $\Theta_{\mathrm{ST}}=$ $0.478(P<0.0001)$. The two $C$. rubidiceps populations had a $\Theta_{\mathrm{ST}}=0.596(P<0.0001)$, and the clades were differentiated by six character changes: five transitions at positions $91,108,114,136$, and 166 , and one transversion at position 607 . 


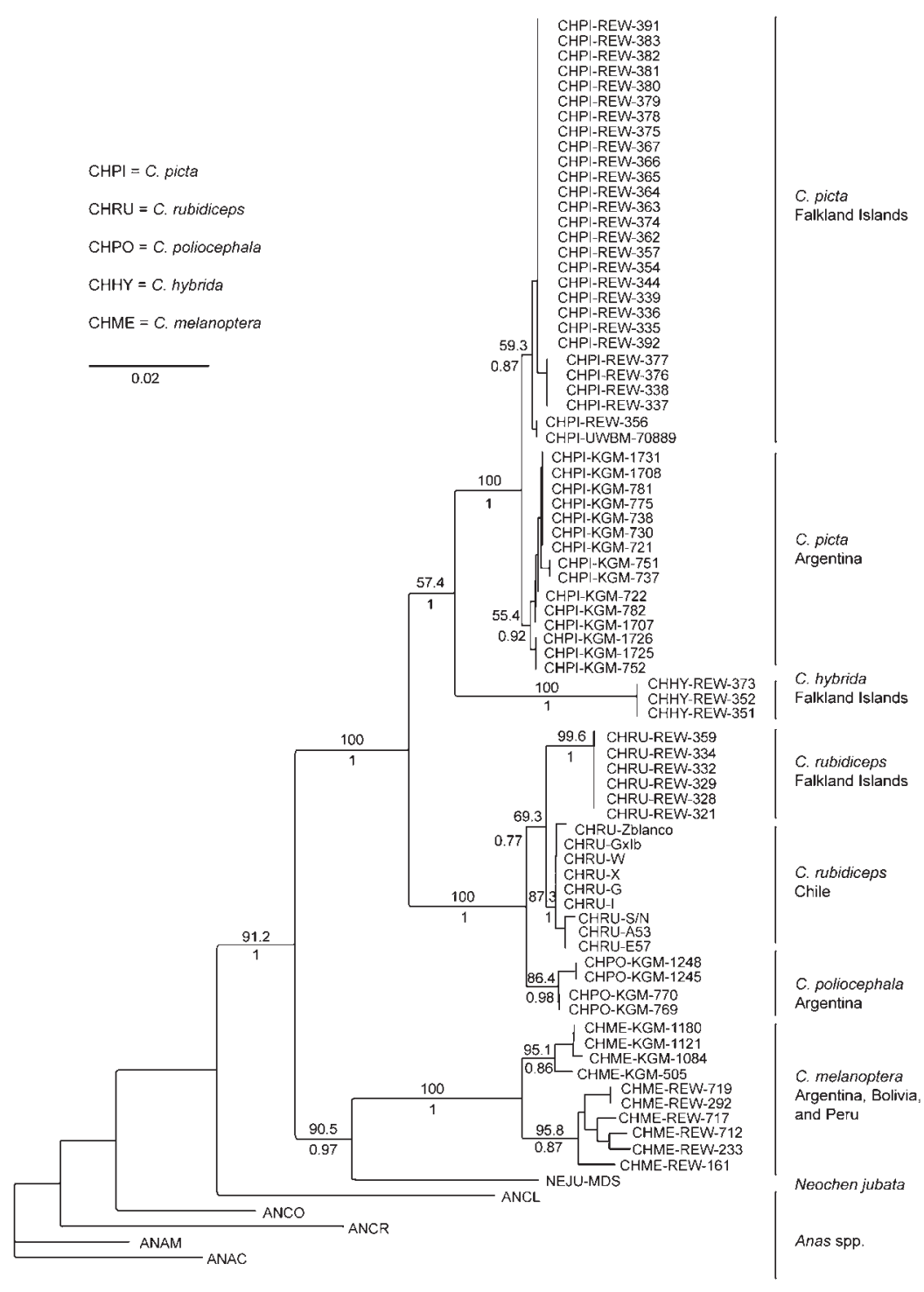

Figure 3. Most likely tree showing the monophyly of Neochen and Chloephaga. The best-fit model was TVM+I+G with $\mathrm{I}=0.6974$ and $\mathrm{G}=2.3108$. Support values above branches correspond to nonparametric bootstrap, and below branches to Bayesian posterior probabilities.

The maximum likelihood tree agrees with the UPGMA tree (Figure 3). Chloephaga hybrida was placed as sister taxon to C. picta with low bootstrap (57.4\%) but high posterior probability (1.00) support. Two reciprocally monophyletic clades of $C$. melanoptera were recovered with an uncorrected sequence divergence of $2.33 \%(1.88-2.67 \%)$, one including three specimens from northwestern Argentina and one from Bolivia (Oruro), and the other one with three specimens from Peru (Ancash, Huancavelica, and Moquequa) and three from Bolivia (La Paz). To our knowledge, this is the first time that a possible differentiation between northern and southern populations of C. melanoptera is acknowledged, warranting further studies. 


\section{Discussion}

\section{Phylogenetic relationships of the sheldgeese}

Previous phylogenetic studies of the sheldgeese were based on behaviour and morphology (Delacour and Mayr 1945, Johnsgard 1961, Livezey 1997). The shelducks of the genus Tadorna and the sheldgeese that included the genera Cyanochen, Alopochen, Neochen and Chloephaga historically were grouped in the monophyletic Tribe Tadornini. Based on morphology, Livezey (1997) confirmed the monophyly of this group. Later, a molecular phylogeny based on mitochondrial DNA included the Tadornini within the Anatinae (Donne-Goussé et al. 2002), and the result has been since confirmed with different datasets and analyses (Gonzalez et al. 2009, Bulgarella et al. 2010); the Tadornini are closer to the true ducks not the geese (Anserinae). The sheldgeese comprise the Neotropical genera Neochen and Chloephaga; the shelducks include the genera Tadorna and Alopochen, whereas Cyanochen is more closely related to Hartlaub's Duck Pteronetta hartlaubi (Gonzalez et al. 2009, Bulgarella et al. 2010). Recently, McCracken et al. (2010) presented the first molecular phylogeny for the sheldgeese that included all six species. However, this study focused on haemoglobin genes and did not include mtDNA or population-level sampling for each of the Chloephaga species. Here, we present a fully resolved mtDNA phylogeny for Chloephaga and Neochen. Chloephaga picta and C. hybrida were found to be sister taxa, as were C. rubidiceps and C. poliocephala, and these two groups are sister to the clade formed by C. melanoptera and N. jubata. The mainland and insular subspecies of C. picta are reciprocally monophyletic as are the two populations of $C$. rubidiceps. Our results are mostly in agreement with those of McCracken et al. (2010). However, they did not find C. picta and C. hybrida to be sister taxa, as these two species did not form a clade in their analyses (see Figure 2 in McCracken et al. 2010).

In this study, mainland and insular populations of $C$. rubidiceps did not share haplotypes, being as divergent from each other as they are from C. poliocephala. This suggests either the lack of gene flow between the islands and the continent or female-biased philopatry or both. Waterfowl are unusual among birds in that females show greater philopatry to natal and breeding areas than do males (Rohwer and Anderson 1988), and sex-biased dispersal has frequently been invoked as a possible explanation for low levels of mtDNA haplotype sharing among geographic regions (Sonsthagen et al. 2009, Bulgarella et al. 2012, Peters et al. 2012). Furthermore, animal mtDNA evolves rapidly, usually reaching reciprocal monophyly within species and is considered to be not recombining. In contrast, nuclear genes have a longer coalescence time (approximately four times that of mtDNA). Consequently, lineage sorting will be complete for mtDNA for some vicariant events for which it will not yet have occurred for nuclear markers. In such cases, mtDNA is more informative than nuclear DNA and therefore considered a 'leading' indicator (Zink and Barrowclough 2008). Multilocus genetic data may be particularly informative about dispersal patterns in sheldgeese because little data on demographics and movements are currently available. Nevertheless, a well-resolved mitochondrial DNA gene tree is a starting point for any phylogeographical investigation and well-supported geographical patterns of mtDNA differentiation can be sufficient to provide a strong inference of evolutionary history (Zink and Barrowclough 2008).

\section{Avian diversification on the Falkland Islands (Malvinas)}

McDowall (2005) concluded that the biota of the Falkland Islands (Malvinas) are almost exclusively Patagonian and must have reached the Islands either across a former land connection or by dispersal across an ocean gap during the Pleistocene. Ponce et al. (2011) demonstrated that during the last glacial maximum (LGM, 24,000 bp) the sea level was approximately 120-140 m below present sea level. At the time, the East and West Falkland Islands (Malvinas) formed a single island four times larger in area than the present day archipelago. This ancient island was separated from the rest of the continent by a strait less than $220 \mathrm{~km}$ wide (Ponce et al. 2011) giving opportunity for dispersal and colonisation. 
Over 200 bird species are recorded in the Falkland Islands (Malvinas) (Woods and Woods 2006), the majority of which are vagrants that do not breed on the islands. Weller (1972) counted II regular species of breeding waterfowl. Nine passerine taxa regularly breed there (Woods and Woods 2006, Campagna et al. 2012). Six of the 11 recorded penguin species breed on the islands, making it one of the richest penguin faunas in the world (McDowall 2005). Seven species of raptors, four dotterels and snipes, and semi-aquatic birds such as herons complete the breeding resident bird list. Recently, there has been a resurgence of interest in the phylogeography of the avifauna of the Falkland Islands (Malvinas) (McCracken and Wilson 2011, Fulton et al. 2012, Campagna et al. 2012).

Using multilocus genetic data, McCracken and Wilson (2011) reported differentiation between insular and mainland populations of Speckled Teal Anas flavirostris, a widespread migratory duck species in southern South America. They found the island population to be significantly differentiated from populations in Argentina in their mtDNA, with four private alleles in the Falkland Islands (Malvinas) population, and at three nuclear loci, with restricted gene flow from the continent; the insular population of Speckled Teal likely comprising a distinct demographic unit. Next, Fulton et al. (2012) studied speciation in steamer ducks Tachyeres spp. finding that the two species of steamer ducks of the Falkland Islands (Malvinas) are indistinguishable from each other based on a single-locus mtDNA, and that this clade is genetically distinct from the three species in continental South America. They placed the divergence between continental and insular steamer ducks between 2.2 and o.6 Mya consistent with the great Patagonian glaciation (GPG; Rabassa et al. 2011) when extensive ice sheets covered Patagonia. Finally, Campagna et al. (2012) studied the divergence between nine mainland and insular passerine populations. They found marked genetic differentiation between the conspecific Troglodytes aedon and T. cobbi, with T. cobbi being the oldest Falkland Islands (Malvinas) land bird that split from continental T. aedon during the GPG of the Pleistocene.

Although we have not dated the divergence between the Falkland Islands (Malvinas) and mainland populations of Chloephaga, several scenarios are possible. First, Chloephaga might have colonised the islands from the continent during the GPG when Patagonia was heavily glaciated and the birds could have found refuge in the unglaciated parts of the islands. Alternatively, the colonisation of the islands might date back to the earlier Pleistocene (or even the Pliocene) with birds dispersing to ice-free areas either in Northern Argentina/Chile or within the Falkland Islands (Malvinas) themselves during the glaciation/deglaciation cycles of the Pleistocene.

Indeed, multilocus phylogeographic analyses are necessary to infer demographic history parameters such as effective population sizes, direction and timing of colonisation, and gene flow but this study is an important first step towards the understanding of the sheldgeese.

\section{Conservation implications}

The Ruddy-headed Goose, C. rubidiceps, has been removed from the threatened species list due to the stability of the insular Falkland Islands (Malvinas) population (BirdLife International 2012). However, the current mainland population of $C$. rubidiceps is estimated to comprise $<1$, ooo individuals and is decreasing (Blanco et al. 2009); therefore, it meets IUCN criterion C (fewer than 2,500 mature individuals in the population; IUCN 2001) and should be classified as 'Endangered'. Unfortunately, we did not include individuals from the wintering population of C. rubidiceps in southern Buenos Aires, Argentina, because the extremely low numbers of individuals made it difficult to obtain samples. It would be useful to collect genetic samples from this population to quantify how much it differs from the Falkland Islands (Malvinas) population. Based on our findings, we suggest that the continental population of Ruddy-headed Goose be considered an evolutionarily significant unit (ESU; sensu Moritz 1994), distinct from the Falkland Islands (Malvinas) population.

Upland Geese populations from the mainland show significant genetic, morphological and ecological divergence from the subspecies in the Falkland Islands (Malvinas). While the C. p. leucoptera population is stable, the continental C. p. picta population appears to have decreased in recent 
years and its status should be considered carefully until more data or estimations of the current population sizes are undertaken. Moreover, for both species, we showed the reciprocal monophyly of the insular and continental populations and the implicit lack of female-mediated gene flow, supporting inferences that these populations have diverged and are geographically isolated units deserving different conservation status than they currently have.

\section{Supplementary Material}

The supplementary materials for this article can be found at journals.cambridge.org/bci

\section{Acknowledgements}

We thank the following people and agencies for their assistance: Dirección de Fauna Silvestre, Secretaría de Ambiente y Desarrollo Sustentable de la República Argentina, Dr. Pablo Tubaro from the Museo Argentino de Ciencias Naturales "Bernardino Rivadavia", Dirección de Fauna y Flora Silvestre del Chubut, Dirección de Fauna de Santa Cruz, Falkland Island Government, and Alan Eagle and Sonia Felton from Fitzroy Farm. Two anonymous reviewers provided helpful comments on the manuscript. ASDG is a CONICET Research Fellow and CK is a Postdoctoral Researcher of IDRC (iBOL, International Barcode of Life Project). Funding was provided by the Institute of Arctic Biology at the University of Alaska Fairbanks, a grant from Frank M. Chapman Fund at the American Museum of Natural History to MB, and NSF grants (DEB-0444748, IOS-0949439) to KGM.

\section{References}

Akaike, H. (1973) Information theory and an extension of the maximum likelihood principle. Pp. $267-281$ in B. N. Petrov and F. Csaki, eds. Proceeding of Second International Symposium on Information Theory. Budapest: Akademia Kiado.

Bandelt, H-J., Forster, P. and Röhl, A. (1999) Median-joining networks for inferring intraspecific phylogenies. Mol. Biol. Evol. 16: $37-48$.

BirdLife International (2012) Species factsheet: Chloephaga rubidiceps. Available at http:// www.birdlife.org/datazone/speciesfactsheet. php?id=394.

Blanco, D. E. and de la Balze, V. M. (2006) Harvest of migratory geese (Chloephaga spp.) in Argentina: an overview of the present situation. Pp. $870-873$ in G. C. Boere, C. A. Galbraith and D. A. Stroud, eds. Waterbirds around the world. A global overview of the conservation, management and research of the world's waterbird flyways. Edinburgh, UK: The Stationery Office.

Blanco, D. E., Matus, R., de la Balze, V. M., Blank, O., MacLean, D., Zalba, S. et al. (2009) Ruddy-headed Geese (Chloephaga rubidiceps) in danger: Population status and conservation actions in Argentina and Chile. Wetlands International Technical Report.

Bottema, C. D. K., Sarkar, G., Cassady, J. D., Li, S., Dutton, C. M. and Sommer, S. S. (1993) Polymerase chain reaction amplification of specific alleles: general method of rapidly detecting mutations, polymorphisms, and haplotypes. Methods Enzymol. 218: 388-402.

Brown, J. H. and Lomolino, M. V. (2000) Concluding remarks: historical perspective and the future of island biogeography theory. Glob. Ecol. Biogeogr. 9: 87-92.

Bulgarella, M., Sorenson, M. D., Peters, J. L., Wilson, R. E. and McCracken, K. G. (2010) Phylogenetic relationships of Amazonetta, Speculanas, Lophonetta, and Tachyeres: four morphologically divergent duck genera endemic to South America. J. Avian Biol. 41: 186-199.

Bulgarella, M., Peters, J. L., Kopuchian, C., Valqui, T., Wilson, R. E. and McCracken, K. G. (2012) Multilocus coalescent analysis of haemoglobin differentiation between lowand high-altitude populations of crested 
ducks (Lophonetta specularioides). Mol. Ecol. 21: 350-368.

Campagna, L., St Clair, J. J. H., Lougheed, S. C., Woods, R. W., Imberti, S. and Tubaro, P. L. (2012) Divergence between passerine populations from the Malvinas - Falkland Islands and their continental counterparts: a comparative phylogeographical study. Biol. J. Linn. Soc. 106: 865-879.

Carboneras, C. (1992) Family Anatidae (ducks, geese and swans). Pp. 536-628 in J. del Hoyo, A. Elliott and J. Sargatal, eds. Handbook of the birds of the world, vol. 1. Barcelona, Spain: Lynx Edicions.

Carson, H. L. and Templeton, A. R. (1984) Genetic revolutions in relation to speciation phenomena: the founding of new populations. Ann. Rev. Ecol. Syst. 15: 97-131.

Clegg, S. M., Degnan, S. M., Kikkawa, J., Moritz, C., Estoup, A. and Owens, I. P. F. (2002) Genetic consequences of sequential founder events by an island-colonizing bird. Proc. Natl. Acad. Sci. USA. 99: 8127-8132.

Crandall, K. A., Bininda-Emonds, O. R. P., Mace, G. M. and Wayne, R. K. (200o) Considering evolutionary processes in conservation biology. Trends Ecol. Evol. 15: 290-295.

Crawshay, R. (1907) The birds of Tierra del Fuego. London: Bernard Quaritch.

Delacour, J. (1954) The waterfowl of the world. Vol. 1. London: Country Life.

Delacour, J. and Mayr, E. (1945) The Family Anatidae. Wilson Bull. 57: 3-55.

Donne-Goussé, C., Laudet, V. and Hänni, C. (2002) A molecular phylogeny of anseriformes based on mitochondrial DNA analysis. Mol. Phyl. Evol. 23: 339-356.

Drummond, A. J., Ashton, B., Buxton, S., Cheung, M., Cooper, A. et al. (2011) Geneious v5.4. Available at http://www.geneious.com/

Emerson, B. C. (2002) Evolution on oceanic islands: molecular phylogenetic approaches to understanding patterns and processes. Mol. Ecol. 11: 951-966.

Excoffier, L. and Lischer, H. E. L. (2010) Arlequin suite ver 3.5: a new series of programs to perform population genetics analyses under Linux and Windows. Mol. Ecol. Res. 10: $564-567$.
Felsenstein, J. (1985) Confidence limits on phylogenies: An approach using the bootstrap. Evolution 39: 783-791.

Fraser, D. J. and Bernatchez, L. (2001) Adaptive evolutionary conservation: towards a unified concept for defining conservation units. Mol. Ecol. 10: 2741-2752.

Fulton, T. L., Letts, B. and Shapiro, B. (2012) Multiple losses of flight and recent speciation in steamer ducks. Proc. R. Soc. B 279 : 2339-2346.

Gonzalez, J., Düttmann, H. and Wink, M. (2009) Phylogenetic relationships based on two mitochondrial genes and hybridization patterns in Anatidae. J. Zool. 279: 310-318.

Green, D. M. (2005) Designatable units for status assessment of endangered species. Conserv. Biol. 19: 1813-1820.

Guindon, S. and Gascuel, O. (2003) A simple, fast, and accurate algorithm to estimate large phylogenies by maximum likelihood. Syst. Biol. 52: 696-704.

IUCN (2001) IUCN Red List categories and criteria: Version 3.1. Gland, Switzerland and Cambridge, UK: IUCN Species Survival Commission.

Johnsgard, P. A. (1961) The taxonomy of the Anatidae. A behavioural analysis. Ibis 103: $71-85$.

Johnsgard, P. A. (1978) Ducks, geese, and swans of the world. Lincoln, Nebraska: University of Nebraska Press.

Kear, J. (2005) Bird families of the world: ducks, geese, and swans. New York: Oxford University Press.

Livezey, B. C. (1997) A phylogenetic analysis of modern sheldgeese and shelducks (Anatidae, Tadornini). Ibis 139: 51-66.

Lomolino, M. V. (2000) A call for a new paradigm of island biogeography. Glob. Ecol. Biogeogr. 9: 1-6.

Madsen, J., Matus, R., Blank, O., Benegas, L., Mateazzi, G. and Blanco, D. E. (2003) Population status of the Ruddy-headed Goose (Chloephaga rubidiceps) in Tierra del Fuego and mainland Patagonia (Chile and Argentina). Ornit. Neotr. 14: 15-28.

Maley,J.M. andWinker, K. (2010) Diversification at high latitudes: speciation of buntings in the genus Plectrophenax inferred from mitochondrial and nuclear markers. Mol. Ecol. 19: 785-797. 
McCracken, K. G. and Sorenson, M. D. (2005) Is homoplasy or lineage sorting the source of incongruent mtDNA and nuclear gene trees in the Stiff-Tailed Ducks (NomonyxOxyura)? Syst. Biol. 54: 35-55.

McCracken, K. G., Barger, C. P. and Sorenson, M. D. (2010) Phylogenetic and structural analysis of the $\mathrm{HbA}(\alpha \mathrm{A} / \beta \mathrm{A})$ and $\mathrm{HbD}$ $(\alpha \mathrm{D} / \beta \mathrm{A})$ hemoglobin genes in two highaltitude waterfowl from the Himalayas and the Andes: Bar-headed goose (Anser indicus) and Andean goose (Chloephaga melanoptera). Mol. Phyl. Evol. 56: 649-658.

McCracken, K. G. and Wilson, R. E. (2011) Gene flow and hybridization between numerically imbalanced populations of two duck species in the Falkland Islands. PLoS One 6(8): e23173.

McDowall, R. M. (2005) Falkland Island biogeography: converging trajectories in the South Atlantic Ocean. J. Biogeogr. 32: 49-62.

Moritz, C. (1994) Defining 'Evolutionary Significant Units' for conservation. Trends Ecol. Evol. 9: 373-375.

Pergolani de Costa, M. J. I. (1955) Las avutardas: especies que dañan los cereales y las pasturas. IDIA 88: 1-9.

Peters, J. L., McCracken, K. G., Zhuravlev, Y. N., Lu, Y., Wilson, R. E., Johnson, K. P. and Omland, K. E. (2005) Phylogenetics of wigeons and allies (Anatidae: Anas): the importance of sampling multiple loci and multiple individuals. Mol. Phyl. Evol. 35: 209-224.

Peters, J. L., Bolender, K. A. and Pearce, J. M. (2012) Behavioural vs. molecular sources of conflict between nuclear and mitochondrial DNA: the role of male-biased dispersal in a Holarctic sea duck. Mol. Ecol. 21: 3562-3575.

Petracci, P. F., Ibáñez, H., Scorolli, A., Cozzani, N., Blanco, D. et al. (2008) Monitoreo poblacional de cauquenes migratorios (Chloephaga spp.) en las provincias de Buenos Aires y Río Negro: Una actualización sobre su estado crítico de conservación. Plan Nacional de Conservación y Manejo de Cauquenes. Buenos Aires, Argentina: Dirección de Fauna Silvestre, Secretaría de Ambiente y Desarrollo Sustentable de la Nación.

Petracci, P. F., Ibáñez, H., Scorolli, A., Faillá, M., Blanco, D. et al. (2009) Monitoreo poblacional de cauquenes migratorios (Chloephaga spp.) en las provincias de Buenos Aires y Río
Negro, julio de 2008. Plan Nacional de Conservación y Manejo de Cauquenes. Buenos Aires, Argentina: Dirección de Fauna Silvestre, Secretaría de Ambiente y Desarrollo Sustentable de la Nación.

Petracci, P. F., Ibáñez, H., Baigún, R., Hollmann, F., MacLean, D. et al. (2010) Monitoreo poblacional de cauquenes migratorios (Chloephaga spp.) en las provincias de Buenos Aires y Río Negro, julio de 2009. Plan Nacional de Conservación y Manejo de Cauquenes. Buenos Aires, Argentina: Dirección de Fauna Silvestre, Secretaría de Ambiente y Desarrollo Sustentable de la Nación.

Ponce, J. F., Rabassa, J., Coronato, A. and Borromei, M. (2011) Palaeogeographical evolution of the Atlantic coast of Pampa and Patagonia from the last glacial maximum to the Middle Holocene. Biol. J. Linn. Soc. 103: 363-379.

Posada, D. and Crandall, K. A. (1998) Modeltest: Testing the model of DNA substitution. Bioinformatics 14: 817-818.

Rabassa, J., Coronato, A. and Martínez, O. (2011) Late Cenozoic glaciations in Patagonia and Tierra del Fuego: an updated review. Biol. J. Linn. Soc. 103: 316-335.

Rohwer, F. C. and Anderson, M. G. (1988) Female-biased philopatry, monogamy, and the timing of pair formation in migratory waterfowl. Pp. 187-221 in R. F. Johnston, ed. Current Ornithology, vol. 5. New York: Plenum Press.

Ronquist, F. and Huelsenbeck, J. P. (2005) MrBayes: Bayesian inference of phylogenetic trees. Version 3.1. Florida State University.

Rumboll, M. A. E. (1975) El Cauquén de Cabeza Colorada (Chloephaga rubidiceps): una nota de alarma. Hornero 11: 315-316.

Scott, P. (1954) South America - 1953. Ann. Rep. Wildfowl Trust 6: 54-69.

Sonsthagen, S. A., Talbot, S. L., Lanctot, R. B., Scribner, K. T. and McCracken, K. G. (2009) Hierarchical spatial genetic structure of Common Eiders (Somateria mollissima) breeding along a migratory corridor. The Auk 126: 744-754.

Sorenson, M. D. and Fleischer, R. C. (1996) Multiple independent transpositions of mitochondrial DNA control region sequences to the nucleus. Proc. Natl. Acad. Sci. USA. 93: 15239-15243. 
Sorenson, M. D. and Quinn, T. W. (1998) Numts: A challenge for avian systematics and population biology. The Auk 115: 214-221.

Sorenson, M. D., Ast, J. C., Dimcheff, D. E., Yuri, T. and Mindell, D. P. (1999) Primers for a PCR-based approach to mitochondrial genome sequencing in birds and other vertebrates. Mol. Phyl. Evol. 12: 105-114.

Storey, B. C., Curtis, M. L., Ferris, J. K., Hunter, M. A. and Livermore, R. A. (1999) Reconstruction and break-out model for the Falkland Islands within Gondwana. J. Afr. Earth Sci. 29: 153-163.

Strange, I. J. (1992) A field guide to the wildlife of the Falkland Islands and South Georgia. London: Harper Collins.

Tamura, K. and Nei, M. (1993) Estimation of the number of nucleotide substitutions in the control region of mitochondrial DNA in humans and chimpanzees. Mol. Biol. Evol. 10: 512-526.

Templeton, A. R. (1980) The theory of speciation via the founding principle. Genetics 94: 1011-1038.
Trewin, N. H., MacDonald, D. I. M. and Thomas, C. G. C. (2002) Stratigraphy and sedimentology of the Permian of the Falkland Islands: lithostratigraphic and palaeoenvironmental links with South Africa. J. Geol. Soc. 159: 5-19.

Weller, M. W. (1972) Ecological studies of Falkland Islands' waterfowl. Wildfowl 23: 25-44.

Weller, M. W. (1975) Habitat selection by waterfowl of Argentine Isla Grande. Wilson Bull. 87: 83-90.

Wetlands International (2006) Waterbird population estimates. Fourth edition. Wageningen: Wetlands International.

Woods, R. W. (1988) Guide to birds of the Falkland Islands. Oswestry, Shropshire, UK: Anthony Nelson.

Woods, R. W. and Woods, A. (2006) Birds and mammals of the Falkland Islands. Maidenhead: WILDGuides.

Zink, R. M. and Barrowclough, G. F. (2008) Mitochondrial DNA under siege in avian phylogeography. Mol. Ecol. 17: 2107-2121.

\section{MARIANA BULGARELLA*}

Ecology Group, Institute of Natural Resources, Massey University, Private Bag 11222, Palmerston North, New Zealand.

\section{CECILIA KOPUCHIAN}

División Ornitología, Museo Argentino de Ciencias Naturales Bernardino Rivadavia, Buenos Aires, Argentina.

\section{ADRIÁN S. DI GIACOMO \\ Laboratorio de Ecología y Comportamiento Animal, Instituto de Ecología, Genética y Evolución de Buenos Aires (IEGEBA-CONICET), Facultad de Ciencias Exactas y Naturales, Universidad de Buenos Aires, Argentina.}

RICARDO MATUS, OLIVIA BLANK

Centro de Rehabilitación Leñadura, Kilómetro 7 Sur, Punta Arenas, Chile.

\section{ROBERT E. WILSON, KEVIN G. MCCRACKEN}

Institute of Arctic Biology, Department of Biology and Wildlife, and University of Alaska Museum, University of Alaska Fairbanks, Fairbanks, AK 99775, USA.

*Author for correspondence; e-mail: M.Bulgarella@massey.ac.nz 